\title{
Dinamica vieții religioase a românilor ortodocși în America de Nord. Istorie și actualitate
}

\author{
Vasile CREȚU*
}

Abstract: The dynamic of the religious life of the orthodox Romanian community in North America. History and current reality. Romanians are a constant presence in North America since the 18th century, when the first Romanian priest is mentioned coming to the United States. Starting with the 19th century, the migration to the North America is thriving, and Romanian presence increased constantly. Thus, the orthodox religious life in the North America witnessed an active presence as well. Shortly, a multitude of parishes began to be formed here, under the jurisdiction of a metropolianate. More and more people came to North America especially after the end of the communist period, and formed other parishes. The activity of the parishes improved as well, as more and more catechetical events or programmes appeared. Therefore, the evolution of the Romanian Christianity in North America is remarkable, as a strong community was formed and is expected to continue evolving. The purpose of this article is to present the evolution of the Romanian orthodox community in North America and to highlight the main steps taken and the milestones of the developements of this community during the last two centuries.

Keywords: Romania, United States, religion, orthodoxy, episcopate, metropolianate, parishes, OCA.

\footnotetext{
* Preot, Conferențiar universitar la Facultatea de Teologie Ortodoxă „Justinian Patriarhul", Universitatea din București, România.
} 


\section{1. Începuturile prezenței românești pe continentul nord-american}

Primele date despre o prezență ortodoxă pe continentul american le avem din secolul al XVIII-lea, când călugări de la Sfântul Valaam sunt trimiși de Ecaterina cea Mare a Rusiei în Alaska. De la momentul sosirii lor, Sfânta Liturghie nu a încetat a fi săvârșită în America de Nord. Primul român consemnat de istorie în aceste părți ale lumii va fi preotul Samuilă Damian care, în 1750, efectua o călătorie în jurul lumii. De altfel, preotul ortodox din Transilvania se va împrieteni cu Benjamin Franklin, de la care va învăța tainele electricității ${ }^{1}$.

Începând cu secolul al XIX-lea, fenomenul imigrației sporește pe acest continent, iar românii nu vor face notă discordantă. Evreii români își fac cunoscută prezența încă din 1880 , pe când ortodocșii români, cu precădere cei din Transilvania, se vor stabili în America abia după 1885. O statistică din anul 1905 arată faptul că, la acea vreme, 7818 români migraseră deja către S.U.A., 7261 de persoane din teritoriile stăpânite de Austro-Ungaria şi doar 557 din Regatul României ${ }^{2}$. Până în 1920, se estimează că peste 50 de mii de români au ajuns în Statele Unite, mare parte din aceștia întorcându-se în țară după încetarea Primului Război Mondial, când are loc și Marea Unire³.

Cauzele și caracteristicile imigrației românești în America de Nord sunt asemănătoare cu cele din Europa. Totuşi, destinele românilor plecați spre Canada diferă de cel al românilor din Statele Unite, deosebiri care marchează esențial modul în care comunitățile din cele două state vecine se for forma. Astfel, în

${ }^{1}$ Ioan ARMași-VARTAn, Biserica Ortodoxă Română în diaspora; scurt istoric și organizare actuală, Universitatea din București, teză de doctorat susținută în anul 2013, rezumat disponibil în https://www.academia.edu/10768941/ Rezumat_teza, (accesat la data de 27.08.2021), p. 173-174.

2 Ioan ARMAȘI-VARTAN, Biserica Ortodoxă Română..., p. 174.

3 https://www.oca.org/cdn/PDFs/dept-archives/orthodox-christians-na.pdf (accesat la data de 28.08.2021). 
S.U.A., românii s-au îndreptat cu precădere spre mari centre industriale, migrând în orașe precum Detroit, Chicago sau New York, în timp ce în Canada, aceștia au ales zonele preponderent agricole, lipsite de populații numeroase, precum Saskatchewan, Alberta, Manitoba. Stiul de viață agricol și lipsa locașurilor de cult au determinat populația din Canada să pună mult mai repede bazele unor parohii ortodoxe românești, precum și a unor societăți social-filantropice.

Prin urmare, în 1901 începe construcția primei biserici românești din America, în Alberta, într-un sat pe care românii 1-au botezat Boian, după regiunea bucovineană de unde emigraseră. Construcția se va finaliza peste câțiva ani, iar locașul de cult va fi sfințit în 1905. În 1902 va lua ființă și parohia ortodoxă din Regina, avându-l ulterior ca slujitor pe arhimandritul Evghenie Ungureanu. În același fel, prin slujitori trimişi din Mitropolia Moldovei, vor lua ființă și alte parohii, ceea ce face ca, până în 1911, numărul lor să crească la opt ${ }^{4}$.

Pentru că majoritatea emigranţilor români în Statele Unite erau originari din părțile de sud ale Transilvaniei, din parohii rurale ortodoxe care se aflau sub jurisdicția canonică a Arhiepiscopiei Sibiului, cel care avut un cuvânt hotărâtor în constituirea unor parohii ortodoxe în America a fost Mitropolitul Ioan Mețianu (1899-1916), sfătuit de tânărul său secretar, Miron Cristea, viitorul Patriarh al României. Vlădica Ioan Mețianu îl va trimite în 1904 pe preotul Zaharie Oprea să cerceteze primele comunități, dar acesta se va întoarce în țară după câteva luni noiembrie 1904 - ianuarie $1905)^{5}$.

În același an, românii din Cleveland (Ohio) pun bazele primei parohii din SUA, cu hramul „Sfânta Maria”, parohie care,

${ }^{4} \mathrm{https} / / /$ www.mitropolia.us/pdf/istoric-mitropolie.pdf, p. 1-2 (accesat la data de 28.08.2021).

${ }^{5}$ Mircea PĂCURARIU, „Mărturii documentare privitoare la diaspora românească din Statele Unite ale Americii la începutul secolului al XX-lea”, în Biserica Ortodoxă Română, promotoare a identității eclesiale, culturale și etnice a românilor din afara României (studii și articole), București, Editura Basilica, 2021, p. 198-200. 
începând cu anul următor, va fi condusă de preotul Moise Balea ${ }^{6}$. Părintele Balea va mai înființa și parohiile din South Sharon (Pennsylvania), Youngstown (Ohio), Indianapolis și Indiana Harbor (Indiana). Începând cu anul 1906, misiunea din Statele Unite sporește prin venirea preoților Trandafir Scorobeț, Ioan Tatu și Simeon Mihălțan, toți sub ascultarea canonică a Mitropolitului Ardealului ${ }^{7}$.

În anul 1912, datorită unui număr suficient de mare de comunități ortodoxe, se va înființa primul Protopopiat, recunoscut de statul american Ohio pe 29 iulie 1913, avându-1 în frunte pe preotul Ioan Podea. Protopopiatul avea în componență 16 parohii și se afla subordonat canonic Mitropoliei Ardealului. Acesta nu cuprindea însă și parohiile din Canada, atât din pricina distanței, cât și a ascultării canonice faţă de scaunul mitropolitan din Iași.

Din cauza schimbărilor survenite la conducerea Mitropoliei de la Sibiu prin instalarea Mitropolitului filo-maghiar Vasile Mangra (1916-1918), românii din Statele Unite s-au întrunit în 1918 pentru a hotărî ruperea legăturilor canonice cu Mitropolia Ardealului. Aceștia vor trimite o scrisoare către Mitropolitul UngroVlahiei, intitulată „Hrisov de închinare și supunere”, prin care solicită luarea în subordine canonică a parohiilor din Statele Unite. Întrucât, imediat după război, Vasile Mangra va fi înlocuit de mitropolitul Nicolae Bălan, Mitropolia de la București alege să nu intervină în chestiunea românilor americani, respectând autonomia eparhială a scaunului de la Sibiu. Creșterea numărului parohiilor, lipsa prezenței unui arhiereu, precum şi exemplul similar al altor ortodocși, a determinat comunitea din S.U.A. să întreprindă măsurile necesare înființării unei episcopii ${ }^{8}$.

6 Vasile PoP, „Diaspora ortodoxă română: accente istorice, misionare și aspecte pastorale actuale", în Teologie și Viață. Revistă de gândire și spiritualitate creștină, 5-8/2017, p. 83.

7 https://www.mitropolia.us/pdf/istoric-mitropolie.pdf, p. 2 (accesat la data de 30.08.2021).

8 https://www.mitropolia.us/pdf/istoric-mitropolie.pdf (accesat la data de 30.08.2021). 
Primele acțiuni în acest sens vor fi luate la Congresul bisericesc din 1923, care are loc în Cleveland. Aici, preoțimea și reprezentanții poporului adoptă un memorandum pe care îl înaintează Sfântului Sinod al Bisericii Ortodoxe Române în vederea întemeierii Episcopiei Ortodoxe Române din America. Autorităţile bisericești de la București nu au considerat oportună o asemenea chestiune până în anul 1928, când Sfântul Sinod îl deleagă pe părintele Trandafir Scorobeț să (re)viziteze Statele Unite pentru a lua pulsul credincioșilor. Sosit pe teritoriul american, părintele Scorobeț începe un turneu al parohiilor americane pentru a se familiariza cu problemele locale. Între timp, în așteptarea unei decizii a Bisericii Ortodoxe Române, multe parohii au decis trecerea lor temporară sub omoforul Episcopului rus de New York, Adam Filipowski ${ }^{9}$.

\section{Alegerea și misiunea primului episcop al românilor din America}

Între 25-28 aprilie 1929 are loc, la parohia Sfântul Gheorghe din Detroit, Congresul clericilor și credincioșilor ortodocşi români din America, prin participarea a 20 preoți și 24 de mireni, sub președinția părintelui Trandafï Scorobeț. Din prezidiul Congresului au mai făcut parte și părintele Octavian Mureşan (parohul bisericii Sfântul Gheorghe), ca notar general, iar preoţii Andrei Moldovanu, Glicherie Moraru şi Ioan Truţa ca notari de şedinţe.

Lucrările Congresului s-au finalizat cu adoptarea unui Statut de organizare al viitoarei eparhii şi cu următoarea hotărâre: „Noi, reprezentanţii parohiilor Ortodoxe Române din America şi Canada, după 25 de ani de viaţă românească în această ţară, în care timp bisericile şi credincioşii noştri au avut mari suferinţe şi lipsuri, hotărâm ca Biserica Ortodoxă Română din Statele Unite şi Canada

9 https://www.mitropolia.us/pdf/istoric-mitropolie.pdf (accesat la data de 30.08.2021). 
să se constituie în Episcopie Autonomă Misionară sub jurisdicţia Sfântului Sinod al României, iar Episcopul nostru să fie membru de drept al Sfântului Sinod al României"10.

La 21 noiembrie 1929, Congresul Naţional Bisericesc al Bisericii Ortodoxe Române validează decizia de înființare a Episcopiei Misionare Ortodoxe Române din America și Canada, iar Sfântul Sinod va aproba aceste hotărâri la 1 noiembrie 1930. Prin Decretul nr. 10219/1930, era învestită o Comisie interimară pentru a organiza, îndruma şi conduce afacerile acestei Episcopii. În aprilie 1934, Patriarhul Miron Cristea, în colaborare cu Guvernul României, a reușit să aducă în atenția Parlamentului ,Legea pentru întemeierea Episcopiei Misionare pentru creştinii ortodocşi români din ţările apusene nonortodoxe", care a fost promulgată ulterior de Regele Carol al IIlea în data de 5 mai 1934. Ca Vicar eparhial, până la alegerea unui episcop, a fost desemnat părintele Ioan Truța ${ }^{11}$.

Toate formalitățile legale fiind îndeplinite, în data de 26 ianurie 1935, Sfântul Sinod al Bisericii Ortodoxe Române îl alege pe starețul mănăstirii Hodoș-Bodrog, Preacuviosul Arhimandrit Policarp Morușca, în demnitatea de Episcop al românilor din America. Hirotonia întru arhiereu a fost săvârșită două luni mai târziu, în paraclisul „Sfântul Gheorghe” al Catedralei Patriarhale din București. $\mathrm{Cu}$ această ocazie, noul episcop a declarat că „Dumnezeu şi Domnul nostru Iisus Hristos, milostivindu-Se spre mine, smeritul Său slujitor, m-a chemat din umbra Sfintei Mănăstiri Hodoş-Bodrog, la înalta demnitate de Episcop Misionar. În duminica de 24 martie 1935, în decursul Sfintei Liturghii, în istoricul paraclis al Sfintei Patriarhii din Bucureşti, am fost hirotonit întru Arhiereu prin punerea mâinilor Î.P.S. Mitropolit Gurie al Basarabiei, cu împreuna lucrare a P.S. Episcop Ghenadie al Buzăului şi a Arhiepiscopului Veniamin, Vicarul Sfintei Mitropolii a Ungro-Vlahiei, iar din mâna Înaltpreasfinţitului Mitropolit Miron, Prea Fericitul Patriarh al României, am primit toiagul de

${ }^{10} \mathrm{https} / / /$ www.mitropolia.us/pdf/istoric-mitropolie.pdf (accesat la 30.08.2021).

${ }^{11}$ Ioan ARMașI-VARTAN, Biserica Ortodoxă Română..., p. 179. 
păstorire"12. În data de 4 iulie 1935, în biserica românească din Detroit, Michigan, Preasfințitul Policarp este instalat ca primul arhiereu al Episcopiei Misionare Ortodoxe din America și Canada.

Printre realizările scurtei păstoriri a episcopului Policarp, putem menționa inițierea revistei Solia a Episcopiei, interesul pentru organizarea administrativă și numeroasele vizite pe care acesta le-a efectuat în comunitățile românești din S.U.A. și Canada. $\mathrm{Nu}$ puţin lucru este și vizita pe care episcopul o va face președintelui american, Franklin D. Roosvelt. De asemenea, Preasfințitul Policarp va achiziționa în 1938 o fermă cu peste 80 hectare de pământ, în scopul înființării unui complex administrativ şi social. Pe terenul respectiv urmau sa fie construite o mănăstire, reședința arhierească, o casă de bătrâni și o tabără pentru tineri. Această construcție administrativ-culturală a fost denumită „,Vatra Românească" şi a jucat un rol important în evoluţia ulterioară a Episcopiei. Până în 1936, eparhia număra deja 44 de parohii, 62 de filii, fiind deservite de 34 de preoți ${ }^{13}$.

În anul 1939, P.S. Policarp Morușca revine în țară pentru o sesiune ordinară a Sfântului Sinod, însă acesta nu va mai ajunge niciodată pe teritoriul american. La doar câteva săptămâni de la sosirea sa în România, izbucnește cel de-Al Doilea Război Mondial, în decursul căruia țara noastră se va poziționa împotriva Aliaților, organism internațional din care făceau parte și Statele Unite ale Americii. Desigur, contextul politic nu i-a permis episcopului să revină pe teritoriul eparhiei sale, dar nici evenimentele care s-au succedat nu au favorizat o astfel de oportunitate.

Faptul că după 23 august 1944 și, mai cu seamă, după încheierea războiului, România intră în sfera de influență sovietică, se reflectă și în interdicția de a părăsi țara pe care arhiereul o primește, considerându-se că este o persoană infiltrată de Occident, un spion al puterilor imperialiste. În tot acest timp, P.S. Policarp Morușca și-a continuat activitatea pastorală în țară, primind diverse ascultări ca locțiitor de episcop al Cetății Albe (1941-1944) și

12 https://www.mitropolia.us/pdf/istoric-mitropolie.pdf (accesat la data de 30.08.2021).

${ }^{13}$ Ioan ARMAȘI-VARTAN, Biserica Ortodoxă Română..., p. 181. 
locțiitor de episcop în Maramureș (1945-1948). Preasfințitul Policarp se va pensiona la mijlocul anului 1948, retrâgându-se în Transilvania, cu domiciliu forțat la Catedrala Reîntregirii din Alba Iulia. Ulterior, va fi s 'tareț al Mănăstirii Sfântul Ioan Botezătorul, din 1955 până la trecerea sa la cele veșnice, în 26 octombrie 1958.

Lipsa chiriarhului locului, precum și situația neclară legată de întoarcerea sa în Statele Unite, au produs o serie de conflicte generate de autoritatea pe care unii preoți și-o arogau asupra conducerii eparhiei. Deși, Preasfințitul Policarp îl însărcinase pe preotul Simeon Mihălțan, președintele Consiliului Episcopesc, cu gestionarea administrativă a eparhiei, se observă cu ușurință opoziția pe care preotul Ioan Truța o crează prin nerespectarea ordinelor lăsate de chiriarh, cât și prin organizarea unei serii de Congrese menite să-l plaseze pe acesta din urmă în fruntea eparhiei americane.

Influența acestui preot a mers atât de departe încât a purtat discuții inclusiv cu reprezentanții diplomatici ai României la Washington D.C., care au înaintat un memoriu Patriarhului Nicodim Munteanu prin care se solicita numirea părintelui Truța la conducerea eparhiei, cu argumentele prezentate anterior de acesta. Sub presiunea timpului, dar și din grijă faţă de comunitatea românească din America de Nord, Sfântul Sinod decide, în ședința din 14 decembrie 1946, retrimiterea de îndată a Episcopului Policarp în Statele Unite ale Americii. Din păcate, hotărârea sinodală nu a putut fi îndeplinită din cauza opoziției autorităților române.

\section{Episcopia autonomă a românilor din America de Nord și de Sud (Patriarhia Română)}

Pentru a nu lăsa eparhia de peste ocean fără un păstor, la începutul anului 1947, Sfântul Sinod a analizat posibilitatea înlocuirii Preasfințitului Policarp cu un nou arhiereu, în persoana episcopului Antim Nica. Sub pretextul vizitei pe care Preasfințitul Antim o efectuase la un moment dat la Moscova, Consiliul Eparhial din America se întrunește pentru a respinge în unanimitate propunerea Patriarhului Nicodim, acuzând autoritățile bisericești de la București că se amestecă în mod nepermis în alegerea unui noi 
ierarh pentru credincioşii din America. La 28 martie 1947 are loc un Congres special care decide revenirea la prevederile statutare din 1932, prin care Episcopia avea o largă autonomie decizională, dorind totuşi menținerea unei oarecare legături canonice şi spirituale cu Biserica mamă. În luna mai a aceluiași an, Sfântul Sinod propune Episcopiei Ortodoxe Române din America şi Canada o nouă listă de candidați pentru postul de episcop titular, menținând inclusiv propunerea episcopului Antim, dar nici de această dată nu s-a luat o decizie. La Congresul care a avut loc la Vatra Românească, în 4-5 iunie 1948, sub președinția preotului Ioan Truța, se ratifică revenirea la situația administrativă din 1932, Episcopia rupându-se astfel de Patriarhia Română ${ }^{14}$.

Acest episod marchează, în mod simbolic, o separare a comunităților românești din Statele Unite ale Americii și Canada față de Patriarhie, ruptură care persistă până în ziua de astăzi. Din acest moment, discuția va evolua pe două planuri, unul privind comunitățile parohiale aflate sub influența preotului Truța, iar celălalt referindu-se la un număr minoritar de parohii care vor întreprinde toate măsurile necesare pentru a rămâne în comuniune canonică cu Patriarhia de la București ${ }^{15}$. În acest conflict a încercat să intervină și Mitropolitul Visarion Puiu, stabilit la Paris, prin numirea arhimandritului Atanasie Oprescu ca vicar pentru America, decizie care s-a lovit de opoziția preoților din America, în special a preotului Truța.

Din dorinţa de a rezolva această situație de criză prelungită și de a scăpa Biserica de influența nefastă a preotului Truța, Congresul bisericesc, întrunit la data de 17 mai 1950, la Detroit, format însă numai dintr-o minoritate a comunităților românești, validează

${ }^{14}$ Ioan ARMAȘI-VARTAN, Biserica Ortodoxă Română..., p. 183-184.

15 Interesant este și faptul că pe site-ul actualei Episcopii Ortodoxe Române din America, cea aflată sub jurisdicția canonică a Bisericii Ortodoxe din America, perioada 1939-1951 este eludată, nefiind menţionate niciunul din evenimentele tulburi care au avut loc în eparhie și care au dus la scindarea acesteia în două centre episcopale diferite. Singura referință pentru acest interval temporal este că episcopia s-a aflat sub conducerea Consiliului Eparhial, coordonat de preotul Ioan Truța. A se vedea https://www.roea.org/history (accesat la data de 30.08.2021). 
alegerea protopopului văduv Andrei Moldovan din statul Ohio în postul de episcop titular, trimițând această propunere Sfântului Sinod pentru validare. Alături de numirea noului episcop, se solicita Patriarhiei și recunoașterea Episcopiei autonome a românilor din America de Nord și de Sud, care să fie în ascultare canonică față de Biserica Ortodoxă Română.

În ședința din 12 iulie 1950, Sfântul Sinod ia act de propunerile comunităţii românești din America și se pronunță în favoarea cererilor acesteia, recunoscându-l pe preotul Andrei Moldovan ca membru cu drepturi depline al Sinodului Bisericii Ortodoxe Române. Datorită incertitudinii legăturilor canonice ale episcopilor din Statele Unite, Sfântul Sinod hotărăște chemarea preotului Andrei Moldovan în țară ,pentru a fi hirotonit la Catedrala Naţională din Alba Iulia de către Mitropolitul Nicolae Bălan şi episcopii (Andrei) Mager, Veniamin şi Policarp" Evenimentul a avut loc pe 12 noiembrie 1950 în Catedrala Mitropolitană din Sibiu, iar ceremonia de învestire o săptămână mai târziu la Palatul Patriarhal, în prezența Patriarhului Justinian Marina. Desigur, hirotonia și alegerea Preasfințitului Andrei nu au fost acceptate de restul comunităților din America, care se rupseseră anterior de Biserica mamă ${ }^{17}$.

Anii de păstorire ai arhiereului Andrei Moldovan, deși scurți, au fost rodnici şi vitali pentru redresarea Episcopiei. Deoarece patrimoniul de la Vatra Românească a fost retrocedat Episcopiei necanonice de către instanțele americane, noul ierarh a decis achiziționarea și înființarea unui nou sediu episcopal în Detroit, Michigan. De asemenea, a fost continuată publicarea revistei Credința, au fost sfințite biserici noi în Statele Unite și în Canada și s-au întărit legăturile canonice cu Biserica din România. Preasfinţitul Andrei a contribuit chiar și la dezvoltarea relațiilor internaţionale ale Bisericii Ortodoxe Române, fiind delegat de

16 Raport nr. 62/1952 adresat Sfântului Sinod, întocmit de preotul Simeon Mihălţan, preotul Petru Moga, Alexandru Suciu şi Nicholas Martin, în Arhiva Sectorului Comunităţi externe, p.12, apud Ioan ARMAȘI-VARTAN, Biserica Ortodoxă Română..., p. 185.

${ }^{17} \mathrm{https}$ ://www.mitropolia.us/pdf/istoric-mitropolie.pdf (accesat la data de 28.08.2021). 
Sfântul Sinod la lucrările Conferinței Pan-ortodoxe din insula Rodhos, care au avut loc în perioada 22 septembrie-2 octombrie 1961. Episcopul Andrei Moldovan moare la data de 14 martie 1963, la Detroit, și va fi înmormântat în cimitirul Woodlawn din oraș ${ }^{18}$.

Întrunit în luna aprilie a anului 1963 pentru a constata vacantarea postului de episcop al românilor ortodocși din America, Sfântul Sinod îl alege în scaunul de ierarh titular pe Preasfințitul Teoctist Arăpașu, episcopul Aradului, ridicându-l totodată la rangul de Arhiepiscop ${ }^{19}$. Intrucât Preasfințitul Teoctist nu a primit viza din partea Statelor Unite, acesta nu a putut lua în posesie canonică Episcopia care i-a fost încredinţată de Sinod, astfel că, în anul 1966, a fost ales un nou chiriarh, în persoana arhimandritului Victorin Ursache $^{20}$, fost superior al așezămintelor românești din Țara Sfântă. Pe lângă pregătirea sacerdotală, părintele Victorin era și un ales erudit, cunoscând cinci limbi (engleză, franceză, germană, greacă și arabă) și activând peste zece ani ca profesor la Seminarul Teologic „Sfântul Tihon” din South Canaan, Pennsylvania. Hirotonia întru arhiereu a episcopului ales a fost săvârșită în data de 7 august 1966, în Catedrala Sfântul Gheorghe din Windsor, Ohio, de către Primatul Arhiepiscopiei Ortodoxe Grecești din America, Arhiepiscopul Iakovos, împreună cu alți doi ierarhi ai Patriarhiei Ierusalimului, Epifanios al Philadelphiei și Aristovoulos de Kyriacoupolis ${ }^{21}$.

Episcopul Victorin a dovedit, în primul rând, o aleasă viață spirituală pe care a încercat să o impregneze și comunității sale. Dincolo de calităţile sale intelectuale, se întrevedeau simplitatea vieții de călugăr și atmosfera de sfințenie pe care o întrupa. O altă preocupare a ierarhului a fost aceea de a consolida legăturile canonice cu Biserica mamă și de reprezentare a acesteia în spațiul

${ }^{18} \mathrm{https} / / /$ www.mitropolia.us/pdf/istoric-mitropolie.pdf (accesat la data de 28.08.2021).

19 https://ro.wikipedia.org/wiki/Teoctist_Ar\%C4\%83pa\%C8\%99u\#Ascensiunea_ c\%C4\%83tre_tronul_de_patriarh (accesat la data de 30.08.2021).

${ }^{20}$ Reținem și faptul că, la data de 23 aprilie 1966, înainte de validarea Sfântului Sinod, în Catedrala românească din Detroit are loc un Congres la care au fost propuşi doi candidați pentru funcția de episcop: Arhim. Victorin Ursache și Arhid. Bartolomeu Anania. Ultimul declină însă candidatura.

${ }^{21}$ https://www.mitropolia.us/pdf/istoric-mitropolie.pdf (accesat la data de 28.08.2021). 
religios internațional, motiv pentru care Victorin Ursache a avut un rol activ în dezvoltarea relațiilor inter-ortodoxe și în cadrul mișcării ecumenice. Pentru meritele deosebite pe care Preasfințitul Victorin le-a avut în păstrarea comuniunii cu Biserica Ortodoxă Română, Sfântul Sinod decide, prin decizia nr. 14079 din 12 decembrie 1974, ridicarea Episcopiei Misionare Ortodoxe Române din America la rang de Arhiepiscopie. Totodată, Sinodul reafirmă autonomia noii Arhiepiscopii și a arhipăstorului ei în gestionarea chestiunilor interne. Tot ca semn de recunoaștere a legăturilor duhovnicești, între 25 aprilie și 15 mai 1979, are loc vizita istorică a Patriarhului Iustin Moisescu în Statele Unite ale Americii, prima vizită a unui întâistătător al Bisericii noastre dincolo de ocean, prilej cu care delegația patriarhală va fi primită inclusiv de președintele american Jimmy Carter ${ }^{22}$.

\section{Episcopia Ortodoxă Română din America de la Vatra Românească (în jurisdicția Orthodox Church of America - OCA)}

Ruptura dintre o parte a comunităților parohiale ortodoxe din America și Patriarhia Română se produsese deja, începând cu anul 1948. Pentru gravele prejudicii aduse ortodoxiei și pentru acțiunile de răzvrătire și neascultare faţă de autoritatea bisericească superioară, preotul Ioan Truța va fi caterisit la data de 23 februarie 1951. Conform normelor statutare, sentința definitivă de caterisire a fost pronunțată la data de 28 mai 1951. Deși, la 4 iulie 1951 are loc primul Congres la Vatra Românească sub conducerea noului Episcop Andrei Moldovan, ședință la care vor participa reprezentanții a 17 parohii, falia dintre cele două comunităţi românești paralele a continuat să se adâncească.

La 5 iulie 1951, preotul Ioan Truța organizează la rândul său un alt Congres, care declară că nu recunoaște numirea Episcopului Andrei în fruntea eparhiei și proclamă autonomie totală față de

22 Mircea PĂCURARIU, Istoria Bisericii ortodoxe Române, vol III, București, Editura Institutului Biblic şi de Misiune al Bisericii ortodoxe Române, 1997, p. 498. 
autoritățile bisericești de la București: „Episcopia Ortodoxă Română din America să fie şi să rămână pe viitor complet autonomă faţă de Biserica Ortodoxă Română din România, nu numai în afacerile sale administrative, ci şi în cele canonice (spirituale), neavând asupra ei nicio valabilitate ordinele, dispoziţiile sau decretele emanate de către Patriarhul sau de către Sfântul Sinod din România"23. De asemenea, Congresul a decis alegerea lui Viorel D. Trifa în postul de episcop-vicar al Episcopiei, continuând să-1 considere pe Preasfințitul Policarp drept chiriarh statutar. Hirotonia noului episcop-vicar a avut loc un an mai târziu, și a fost săvârșită de Mitropolitul John Theodorovich al Bisericii Ortodoxe Ucrainiene, după ce toate Episcopiile canonice au refuzat să participe la hirotonie.

Astfel, această situație a ridicat o nouă problemă Episcopiei de la Vatra Românească, aceea a canonicitații episcopului său și, implicit, a întregii eparhii. Timp de aproape opt ani de zile, Episcopia de la Vatra Românească a rămas fără legături canonice precise, Preasfințitul Valerian afirmând la acea vreme că se așteaptă eliberarea României de forțele comuniste în vederea restabilirii relațiilor cu Biserica Ortodoxă Română. Cum dezideratul de comuniune cu Patriarhia Română întârzia să fie realizat, Preasfințitul Valerian Trifa aderă împreună cu Episcopia sa în anul 1960 la Mitropolia Rusă de la New York (Biserica Ortodoxă Rusă din America), devenită ulterior, în 1970, Biserica Ortodoxă din America (Orthodox Church of America - OCA) ${ }^{24}$. În același an, Valerian Trifa primește titlul de Arhiepiscop.

Din punct de vedere pastoral-misionar, Episcopia de la Vatra Românească s-a implicat, pe parcursul conducerii ei de către Valerian Trifa, în catehizarea tinerilor și în creșterea acestora în spiritul credinței ortodoxe. Încă din anii 1950 au fost puse bazele Tineretului Ortodox Româno-American și au fost organizate tabere de vară în scop educaţional, întruniri care au continuat neîntrerupt până în prezent. Taberele de la Vatra Românească sunt astăzi

${ }^{23}$ Ioan ARMAȘI-VARTAN, Biserica Ortodoxă Română în diaspora, p. 186-187.

${ }^{24}$ https://www.roea.org/history (accesat la data de 30.08.2021). 
realizate pentru a deservi două grupe de tineri, una cu vârste cuprinse între 11-13 ani, iar cealaltă pentru adolescenții între 14-17 ani. Din cauza distanțelor mari, alte două tabere educaționale au fost organizate în Canada: una la Toronto, iar cealaltă la Montreal. De asemenea, tot sub conducerea Arhiepiscopului Valerian, a continuat publicarea revistelor catehetice Solia și a mai multor cărți de cult menite bunei desfășurări a activității liturgice ${ }^{25}$.

Pe lângă provocările în plan pastoral, Valerian Trifa a avut de înfruntat și acuzaţii de natură politică, iniţiate de Moses Rosen, rabin al comunității evreiești din România, legate de presupusa activitate legionară intensă în perioada anilor '40, în calitate de conducător al Pogromului de la București. Încă din 1961, Episcopul Valerian va fi judecat de către tribunalele americane care, conform memoriilor Generalului Mihai Pacepa, ar fi primit documente falsificate din partea Serviciilor secrete comuniste din țară, prin care se atestau anumite crime ale arhiepiscopului din perioada sa de studenție. În urma unui proces costisitor (peste $100.000 \$$ din partea Episcopiei Vatra Românească $\breve{a}^{26}$ ) care a stârnit curiozitatea presei vremii, arhiereul își va pierde calitatea de cetățean american în 1980. Cum Justiţia americană a ordonat deportarea ierarhului, acesta va părăsi definitiv Statele Unite în anul 1984, primind azil politic în Portugalia, unde va muri pe 28 ianuarie $1987^{27}$.

Din anul 1984, Episcopia de la Vatra a fost condusă de Preasfinţitul Nathanael Popp, care a continuat în mare parte activitățile administrative ale predecesorului său. După căderea regimului comunist, o oarecare legătură cu Biserica Ortodoxă Română a început să se formeze, dar dialogul a fost reluat oficial abia din 1992. Printre reușitele acestui dialog se pot aminti

${ }^{25} \mathrm{https}$ ://www.roea.org/history (accesat la data de 30.08.2021).

26 „,Religion: The Case of Archbishop Trifa”, în Time, 8 septembrie 1980, disponibil la http://content.time.com/time/subscriber/article/0,33009,924412 ,00.html (accesat la data de 2.02.2021).

27 Ari L. Goldman, ,Valerian Trifa, an Archbishop with a fascist past, dies at 72", în The New York Times, 29 ianuarie 1987, disponibil la https://www.nytimes.com/1987/01/29/obituaries/valerian-trifa-an-archbishopwith-a-fascist-past-dies-at-72.html?searchResultPosition=1 (accesat la data de 29.08.2021). 
restabilirea comuniunii euharistice și cea a împreună slujirii a preoților celor două eparhii ortodoxe românești.

\section{Revitalizarea organizării religioase după căderea comunismului (1989)}

Spre sfârşitul anului 1999, Sfântul Sinod ia în discuție propunerile Arhiepiscopului Victorin referitoare la alegerea unui episcop-vicar (arhim. Vasile Vasilachi sau ierom. Avacum Bucălae). Pentru a nu știrbi autonomia eparhiei și a-i sprijini deciziile statutare, Sfântul Sinod a decis delegarea Preasfințitului episcop-vicar patriarhal Teofan Sinaitul la Congresul Arhiepiscopiei Ortodoxe Române din America și Canada. Constatând că situația administrativă din această eparhie se degradează iremediabil, Sfântul Sinod recomandă în ședința din 4 octombrie 2000 ca Arhiepiscopul Victorin să se retragă din scaun, păstrându-și în mod onorific titulatura și demnitatea episcopală, decizie confirmată în mod staturar în ședința Sfântului Sinod din 22 februarie 2001. Înaltpreasfințitul Victorin va trece la cele veșnice pe data de 16 iulie 2001, la vârsta de 89 de ani, fiind înmormânta la Mănăstirea Putna ${ }^{28}$.

Interimatul acestei Arhiepiscopii a fost asigurat, pentru câteva luni, de Mitropolitul Teofan al Olteniei, până la ședința sinodală din 4-5 iulie 2001, când mandatul de Arhiepiscop Locțiitor este încredințat Mitropolitului Iosif al Europei Occidentale și Meridionale. La trecerea la cele veșnice a Î.P.S. Victorin, așa cum reiese din revista Credința din anul 2001, Arhiepiscopia Ortodoxă Română din America și Canada era compusă din 16 parohii și un schit în Statele Unite ale Americii, 20 de parohii în Canada și o parohie în America de Sud, toate acestea deservite de 35 de preoți și doi diaconi ${ }^{29}$.

Eparhia a avut o conducere ierarhică interimară până în luna martie a anului 2002, când Sfântul Sinod al Bisericii

${ }^{28}$ Ioan ARMAȘI-VARTAN, Biserica Ortodoxă Română..., p. 191-192.

${ }^{29}$ https://www.mitropolia.us/pdf/istoric-mitropolie.pdf (accesat la data de 28.08.2021). 
Ortodoxe Române, urmând hotărârii Congresului electoral al Arhiepiscopiei Statelor Unite și Canadei, validează alegerea Protosinghelului Nicolae Condrea în demnitatea de arhiepiscop al românilor din America. Hirotonia și instalarea oficială a noului chiriarh au fost prezidate de către Preafericitul Părinte Patriarh Teoctist la Montreal, în Canada.

Printre măsurile de revitalizare a vieții pastorale a românilor din această eparhie putem aminti mutarea Centrului Eparhial și a Catedralei de la Detroit în orașul american Chicago, în urma achiziției unei biserici prezbiteriene coreene pe $\mathrm{N}$. Newland Ave (în anul 2003), îmbunătățirea și adoptarea unui nou statut pentru organizarea și funcționarea eparhiei (în anul 2006), dar și alegerea unui episcop-vicar în persoana Preasfinţitului Părinte Ioan Casian de Vicina (tot în anul 2006).

Faptul că prezența românească de pe acest continent a sporit semnificativ este demonstrat și de un studiu publicat în anul 2010 de Institutul Hartford pentru Cercetare Religioasă, în care se constată că în primii zece ani ai mileniului al treilea, Biserica Ortodoxă Română a înregistrat, pe teritoriul american, o creștere a parohiilor de peste $122 \%$, ocupând locul al doilea din perspectiva dezvoltării, după Biserica Ortodoxă Bulgară. Același studiu remarca însă și numărul mic al ortodocşilor români practicanți, care frecventau cu regularitate locașurile de cult doar în proporție de $20 \%{ }^{30}$.

Totuşi, eparhia din America a continuat să facă eforturi susținute pentru menținerea legăturii cu tinerii și copiii, fiecare parohie având o școală de duminică, activități catehetice sau tabere cu tematică religioasă. În plus, s-au pus bazele Organizaţiei de Tineri Români Ortodocşi din America (Romanian Orthodox Youth of America - ROYA), care îşi propune coagularea cât mai multor tineri români în jurul Bisericii şi valorilor creștine ${ }^{31}$.

\footnotetext{
30 https://ziarullumina.ro/actualitate-religioasa/stiri/bor-inregistreaza-o-crestereimportanta-in-sua-20678.html (accesat la data de 26.08.2021).

${ }^{31} \mathrm{http}: / / w w w . r o r t h o d o x y o u t h . c o m /$ (accesat la data de 01.09.2021).
} 
Datorită intensificării prezenței românești pe continentul nord american, cât și a nevoilor pastoral-misionare, Sfântul Sinod al Bisericii Ortodoxe Române a decis, în ședința sa din 28-29 octombrie 2016, ridicarea Arhiepiscopiei Ortodoxe Române a celor două Americi la rang de Mitropolie și reorganizarea teritorială a eparhiei prin redenumirea Arhiepiscopiei Ortodoxe Române a Statelor Unite și înființarea Episcopiei Ortodoxe Române a Canadei, eparhie sufragană a noii Mitropolii ${ }^{32}$. Pentru păstorirea celor peste 192 de mii de persoane de origine românească din Canada ${ }^{33}$, Preasfințitul Părinte Ioan Casian de Vicina a fost desemnat să continue lucrarea pastorală.

Un lucru inedit, care merită menționat, este acela că în subordinea Mitropoliei celor două Americi se află și două parohii din America de Sud. În Venezuela, unde sunt stabiliţi aproximativ 10 mii de români, parohia Sfinții Împăraţi Constantin și Elena a luat ființă încă din anul 1968, la inițiativa preotului Costică Popa. În anul 1999, în aceeași parohie s-a ridicat o biserică de lemn în stil maramureșean, sfințită de Preafericitul Părinte Patriarh Teoctist. În Argentina, pe data de 27 iunie 2003, Patriarhia Română emite un decret prin care se arată că la cererea credincioșilor de aici s-a constituit parohia ortodoxă română din Buenos Aires, bucurându-se de toate drepturile prevăzute de sfintele canoane și de legislația bisericească $\breve{~}^{34}$.

În contextul pandemiei de COVID-19, Institutul Hartford pentru Cercetare Religioasă pe care 1-am menționat anterior, a publicat un nou studiu care analizează impactul situației curente asupra vieții comunităţilor ortodoxe din Statele Unite. După cum era de așteptat, urmând prevederile autorităților americane,

32 Tomos Sinodal nr. 1/2016, emis în temeiul hotărârii Sfântului Sinod al Bisericii Ortodoxe Române, nr. 9138 din 28-29 octombrie 2016, conform prevederilor art. 133, alin 2 din Statutul pentru organizarea şi funcţionarea Bisericii Ortodoxe Române.

${ }^{33} \mathrm{https}$ ///ottawa.mae.ro/node/286m (accesat la data de 01.09.2021).

${ }^{34}$ https://mitropolia.us/pdf/istoric-mitropolie.pdf (accesat la data de 01.09.2021). 
peste $64 \%$ din parohiile ortodoxe din SUA s-au adaptat prezenței în mediul online, transmițând live diversele servicii religioase. Interacțiunea online a avut două urmări: pe de-o parte, multe persoane care nu aveau acces la lumea digitală au întâmpinat dificultăți în menținerea legăturii spirituale cu parohia pe care o frecventau în mod uzual; pe de altă parte, $44 \%$ din persoanele participante la studiu au declarat că prezența lor online la slujbe a fost mult mai crescută decât în perioada în care participau fizic în cadrul cultului divin public ${ }^{35}$. În privința Sfintelor Taine, studiul a relevat faptul că doar un număr foarte mic de preoți $(16 \%)$ au reușit să găsească noi modalităţi prin care să administreze Taina Sfintei Euharistii enoriaşilor pregătiți în acest sens, în timp ce majoritatea preoților au oferit Împărtășania doar unor categorii limitate de credincioși. În comparație cu Taina Euharistiei, celelalte Sfinte Taine au fost ,puse în așteptare”, doar una din șase parohii continuând să săvârșească Taina Cununiei, a Botezului sau a Mirungerii (și a trecerii la credința ortodoxă) ${ }^{36}$.

În egală măsură, o latură foarte afectată a vieții religioase a fost aceea a educației copiilor și a catehizării adulților. Mai puțin de jumătate din parohiile ortodoxe americane se pare că au reușit să mențină o anumită recurență a întrunirilor (online) cu tinerii, copiii și adulții. Puțin peste $25 \%$ dintre preoți au găsit metode inovative prin care să aibă o interacțiune constantă cu copiii, majoritatea activităților având ca soluţie următoarele metode: întâlniri cu tinerii şi copiii pe platforma zoom după fiecare serviciu liturgic, conferințe cu participarea episcopului locului, postarea de videoclipuri cu tematică special destinată celor mici, scurte întâlniri de maximum 30 de minute între profesori și copii pe subiecte religioase ${ }^{37}$.

35 Alexei Krindatch, The Pandemic and American Orthodox Christian Parishes, Hartford Institute for Religion Research, 2020, în https://faithcommuni tiestoday.org/wp-content/uploads/2020/05/CoronavirusUSOrthodoxParishes Report_Phase2.pdf (accesat la data de 01.09.2021).

${ }^{36}$ Alexei KRINDATCH, The Pandemic and..., p. 17.

${ }^{37}$ Alexei Krindatch, The Pandemic and..., p. 16. 
60380

\section{Bibliografie}

1. „Religion: The Case of Archbishop Trifa”, în Time, 8 septembrie 1980, disponibil la Krindatch, Alexei, The Pandemic and American Orthodox Christian Parishes, Hartford Institute for Religion Research, 2020.

2. ARMAȘI-VARTAN, Ioan, Biserica Ortodoxă Română în diaspora; scurt istoric și organizare actuală, Universitatea din București, teză de doctorat susţinută în anul 2013, rezumat disponibil în https://www.academia.edu/10768941/Rezumat_teza (accesat la data de 27.08.2021).

3. Goldman, Ari L., „Valerian Trifa, an Archbishop with a fascist past, dies at 72", în The New York Times, 29 ianuarie 1987, disponibil la adresa https://www.nytimes.com/1987/01/29/ obituaries/valerian-trifa-an-archbishop-with-a-fascist-past-dies-at72.html?searchResultPosition=1 (accesat la data de 29.08.2021).

4. PĂCURARIU, Mircea, Istoria Bisericii ortodoxe Române, vol III, București, Editura Institutului Biblic şi de Misiune al Bisericii ortodoxe Române, 1997.

5. IDEM, „Mărturii documentare privitoare la diaspora românească din Statele Unite ale Americii la începutul secolului al XX-lea", în Biserica Ortodoxă Română, promotoare a identității eclesiale, culturale și etnice a românilor din afara României (studii și articole), București, Editura Basilica, 2021.

6. POP, Vasile, „Diaspora ortodoxă română: accente istorice, misionare şi aspecte pastorale actuale", în Teologie și Viață. Revistă de gândire și spiritualitate creștină, 5-8/2017.

7. http://content.time.com/time/subscriber/article/0,33009,924412, 00.html, accesat la data de 2/2/2021.

8. http://www.rorthodoxyouth.com/ (accesat la data de 01.09.2021).

9. https://mitropolia.us/pdf/istoric-mitropolie.pdf (accesat la data de 01.09.2021).

10. https://ottawa.mae.ro/node/286 (accesat la data de 01.09.2021).

11. https://ro.wikipedia.org/wiki/Teoctist_Ar\%C4\%83pa\%C8\%99u \#Ascensiunea_c\%C4\%83tre_tronul_de_patriarh (accesat la data de 30.08.2021). 
12. https://www.mitropolia.us/pdf/istoric-mitropolie.pdf (accesat la data de 30.08.2021).

13. https://www.mitropolia.us/pdf/istoric-mitropolie.pdf (accesat la data de 30.08.2021).

14. https://www.mitropolia.us/pdf/istoric-mitropolie.pdf (accesat la data de 30.08.2021).

15. https://www.mitropolia.us/pdf/istoric-mitropolie.pdf (accesat la data de 30.08.2021).

16. https://www.mitropolia.us/pdf/istoric-mitropolie.pdf (accesat la data de 28.08.2021).

17. https://www.mitropolia.us/pdf/istoric-mitropolie.pdf (accesat la data de 28.08.2021).

18. https://www.mitropolia.us/pdf/istoric-mitropolie.pdf (accesat la data de 28.08.2021).

19. https://www.mitropolia.us/pdf/istoric-mitropolie.pdf (accesat la data de 28.08.2021).

20. https://www.mitropolia.us/pdf/istoric-mitropolie.pdf, p. 2 (accesat la data de 30.08.2021).

21. https://www.mitropolia.us/pdf/istoric-mitropolie.pdf, p. 1-2 (accesat la data de 28.08.2021).

22. https://www.oca.org/cdn/PDFs/dept-archives/orthodox-christiansna.pdf (accesat la data de 28.08.2021).

23. https://www.roea.org/history (accesat la data de 30.08.2021)

24. https://www.roea.org/history (accesat la data de 30.08.2021).

25. https://ziarullumina.ro/actualitate-religioasa/stiri/bor-inregistreazao-crestere-importanta-in-sua-20678.html (accesat la data de 26.08.2021). 